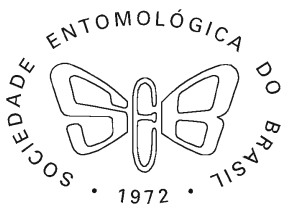

\title{
The Value of Crop Production and Pollination Services in the Eastern Amazon
}

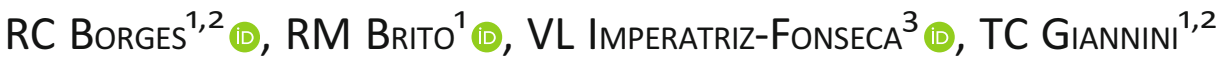 \\ ${ }^{1}$ Instituto Tecnológico Vale Desenvolvimento Sustentável, Belém, Pará, Brasil \\ ${ }^{2}$ Univ. Federal do Pará, Belém, Pará, Brasil \\ ${ }^{3}$ Univ. de São Paulo, São Paulo, Brasil
}

\section{Keywords}

Nature's contribution to people, food security, human well-being, economic vulnerability, açaí, global changes

\section{Correspondence}

RC Borges, Instituto Tecnológico Vale 22 Desenvolvimento Sustentável, Rua Boaventura da Silva, 955, Nazaré, Belém, Pará; 66055-090, Brasil; rcabralsan@gmail.com

Edited by Carmen S S Pires - Embrapa

Received 15 September 2019 and accepted 26 May 2020

Published online: 15 June 2020

(C) The Author(s) 2020

\begin{abstract}
Nature safeguards living organisms and the ecosystem functions and services delivered by them. Animal pollination is an important Ecosystem Service since it plays a key role for achieving the sustainable development goals by safeguarding worldwide food production. Thus, conservation of pollination services is a major priority for guaranteeing global food security in the long term. Here we evaluate the crop pollination services in Pará state (Eastern Amazon, Brazil) focusing on two questions: (1) What is the economic value of crop production and pollination service in Pará? (2) Which municipalities are most dependent on pollination services considering local economies? We found 36 crops produced in the state; 20 (55\%) crops are dependent on animal pollinators. In 2016, crop production value (CPV) for Pará state was US\$2.95 billion and total pollination service value (PSV) was US\$ 983.2 million, corresponding to $33 \%$ of CPV in Pará. Highest PSV value crops were açaí palm (US\$635.6 million), cocoa (US\$187.6 million), soybean (US\$98.4 million), and watermelon (US\$26.1 million), accounting for $96 \%$ of Pará's PSV. Two municipalities (Medicilândia and Igarapé Miri) presented more than 50\% of their GDP based on pollination services. In general, we found low crop diversity in the municipalities of Pará, suggesting an economic rural vulnerability for the state, mainly supported by the high productions of soy and açaí. Pollinator conservation and ecological intensified farming practices are urgent for supporting sustainable development for the state.
\end{abstract}

\section{Introduction}

Nature safeguards living organisms and the ecosystem functions and services delivered by them; however, the ongoing anthropogenic-induced global changes resulted in an unprecedented decline in biodiversity and its contributions to people (Diaz et al 2019). In 2015, the United Nations (UN) (with global support) raised the Sustainable Development Goals (SDGs) aiming to address the maintenance of ecosystem functions and services to both current and future generations (UN 2015). Altogether, the 17 SDGs target to cease poverty and other deprivations while promoting education, equality, food security, and sustainable economic development. Food security remains a great challenge for several countries around the globe as hunger and undernourishment continue to increase (FAO et al 2019). In the future, it may become even harder to achieve considering current trends of climatic changes (Schmidhuber \& Tubiello 2017) and the current scenario of reduction in the provision of ecosystem services around the globe (Diaz et al 2019).

At least $75 \%$ of the leading world crops depend, on some degree, on animals for their reproductive success (Klein et al 2007); therefore, conservation of pollination services is a major priority for guaranteeing global food security in the 
long term (Potts et al 2016). A robust theoretical foundation has been converted to develop best practices aiming to transcend conventional farming into ecological intensified farming (i.e., replacement of anthropogenic inputs by enhancing Ecosystem Services provision) (Bommarco et al 2013, Bommarco et al 2018, Garibaldi et al 2014, Kleijn et al 2019) as a means to ensure biodiversity conservation and food security in sustainable environments. Ecosystem services (ES) are the benefits delivered by nature to guarantee human sustain and well-being (Daily et al 1997, Constanza et al 1997, Braat \& de Groot 2012, but see Diaz et al 2015). Over the last 20 years, several ES-based conservation strategies, policies, and programs have been raised to assist sustainable development goals in a changing world (Wood et al 2018).

Incorporating the economic contribution of pollination services to the market value of dependent crops is an important device for improving land use planning practices focusing on long-term ES provision and nature conservancy (Breeze et al 2016). Monetary valuation of pollination services at global (Gallai et al 2009), national (Giannini et al 2015a), and local scales (Barfield et al 2015, Hipólito et al 2019) has been accessed by applying the dependence ratio method. This method evaluates the market value of pollination services, taking into account the dependence ratios of animal pollination for crop production (Gallai \& Vaissiere 2009, for dependence ratios, see Klein et al 2007 for worldwide crops and Giannini et al 2015a for Brazilian crops). This approach enables a more accurate valuation, closer to real-life value of pollination services, and helps predicting the potential production loss in the case of pollinator decline or complete disappearance, and its consecutive impacts on food production and human well-being.

Crop production in Brazil has accounted for more than $5 \%$ (US\$86 billion) of the country's gross domestic product (GDP) in 2016, according to the Brazilian Institute of Geography and Statistics (IBGE), this being a high value when compared to high-income countries that have less than $2 \%$ (Schmidhuber \& Tubiello 2017). About $60 \%$ of Brazilian crops are pollinator dependent, which account for one third of the country's agricultural market value (Giannini et al 2015a). In addition, about $60 \%$ of the food consumed by Brazilian population is derived from pollinator-dependent crops, representing 21 of the 53 major crops (Novais et al 2016). Although this is a high and expressive value, it is not yet final, as many local crops are not included in these studies since they are not present in IBGE's list, especially those in Brazilian north and northeast regions (Giannini et al 2015b). A good example of a local crop only recently (PAM 2016) added to IBGE's crop list is the now worldwide trade açaí fruit (Euterpe oleracea Mart.). Açaí production corresponds to about $30 \%$ of non-timber production in Brazil; mainly, its production takes place in floodplain forests (várzeas) of northern Brazil and its dependence ratio on pollinators has been recently classified as great (i.e., about $65 \%$ of fruit production is related to animal pollination) (Campbell et al 2018). Although açai production is commonly seen as a product of agroforestry and extractivism activities, this perspective is changing given its current market value (Brondizio et al 2002), and both floodplain and mainland açai monoculture production systems are rising (Brondizio 2004, Weinstein \& Moegenburg 2004, Silva et al 2020, Silva et al 2019).

Northern Brazil is essentially an Amazonian domain area, a biome that is under high anthropogenic pressures historically associated with land use change (Almeida et al 2016, SouzaFilho et al 2016, Sonter et al 2017). Also, pollinator decline has been forecasted for Amazonian bees, birds, and bats in the future (Costa et al 2018, Miranda et al 2019, Giannini et al 2020) and deforestation can contribute to climate change, potentially increasing land surface temperature up to $1.45^{\circ} \mathrm{C}$ by 2050 (Prevedello et al 2019). The resulting impacts of climate change on ES delivered by biodiversity could be detrimental to human well-being ( $O^{\prime} \mathrm{Neill}$ et al 2018) and is urgent to anticipate them aiming to help on conservation policy and decision-making processes. Recently, a local study (eastern Amazon, Pará state) estimated the pollination service value provided by a protected area to surrounding crop production to be about half a million dollars (Hipólito et al 2019), which support the current need for pollinator conservation strategies to keep up the local economy.

The state of Pará (Eastern Amazon) suffers with the highest deforestation rate in the Brazilian Amazon (Brasil, INPE 2019), being infrastructure, power, mining, pasture, and agriculture among its main drivers. Historically, the state's economy has been considered to be based on the extraction of natural goods (extractivism activities, i.e., timber, minerals, seeds, and fruits) (Camilotti et al 2020, lorio \& Monni 2020) and, although expanding, crop production is considered a marginal aspect of the local economy.

Our objectives are to evaluate the crop pollination services in Pará state (Eastern Amazon, Brazil) and understand the role of agriculture to the state's economy. We focus on answering two questions: (1) What is the economic value of crop production and pollination service in Pará? (2) Which municipalities are most dependent on pollination services considering their local economies? We aim to highlight regions and municipalities in the state where crop production and pollination services play a main role in the local economy and where public policies on pollination conservation are more urgent to safeguard socioeconomic development and food security.

\section{Material and Methods}

\section{Study location}

The Pará state is the second largest state in Brazil and the 13th largest state in the world. It is located on the eastern portion of the Brazilian Amazon basin and encompasses an area of more 
than 1.2 million $\mathrm{km}^{2}$. The population is estimated to be 8.5 million inhabitants, with a 0.646 HDI (Human Development Index), among the lowest in the country (24 out of 27) (IBGE 2017). The state is divided into 144 municipalities, with a considerable variation in extent (from $103.34 \mathrm{~km}^{2}$ in Marituba to $159,533.32 \mathrm{~km}^{2}$ in Altamira, the largest Brazilian municipality, being larger than Switzerland) and population (from 3310 in Bannach to 1,485,732 at the state's capital, Belém) (IBGE 2018). Based on the production structure and spatial interactions, Brazilian municipalities are grouped into microregions (IBGE 1990), which support a better understanding of socio-economic traits at local scale. Therefore, Pará state is divided into 22 microregions that group from 2 to 13 municipalities together.

The state is an Amazon domain area, mainly composed by forest formations, but also presenting natural areas of open vegetation (Pires \& Prance 1985). Presently, Pará is located at the eastern portion of the Amazon arc of deforestation (areas of the legal Brazilian Amazon under highest anthropogenic pressures and that present the highest rates of deforestation). Of the 144 municipalities, 17 have the status of Priority Municipalities for conservation actions (Assunção \& Rocha 2019), a list created by the Brazilian Ministry of Environment to target the 45 municipalities with higher deforestation rates in the Brazilian Amazon. In 2016, the gross domestic product of Pará state was about US\$ 37 billion and about $12 \%$ of this value was related to farming production (both livestock and crop production). The remaining value is related to industry, services, and extraction of natural resources (e.g., seeds, timber, and minerals) (IBGE 2018). About one fourth of the state's working force is employed in agriculture activities (980 thousands out of 3.8 million people, both in crop and in pasture activities), being one sixth the average for the country (IBGE 2018). Pará is one of the biggest markets for tropical fruits in Latin America and has arisen in the national context for its potential for power and natural resources production, being considered the new frontier for capital expansion in Latin America (Iorio \& Monni 2020).

\section{Economic value of crop production}

We acquired data on crop production value from the Brazilian Institute of Geography and Statistics (IBGE) for each crop produced in Pará state and for each municipality for the year of 2016 (Electronic Supplementary Material 1). For three municipalities (Belém, Marituba, and Benevides), information on crop production for 2016 was not available; for this, we used data of 2017.

\section{Pollination service valuation}

To estimate the economic market value of pollination services provided by animals to agricultural crops in Pará state (Brazil), the economic production value of each crop was multiplied by the animal pollinator dependency ratio (DR) for crop production, according to the dependence ratio method, proposed by Gallai et al (2009). We used DR values following the classifications of Klein et al (2007) (international crops), Giannini et al (2015a) (Brazilian crops), and Campbell et al (2018) (for the local açaí crop), as follows: (i) essential (crop dependence of 90 to $100 \%$ of animal pollinators, DR = 0.95); (ii) high (from 40 to $90 \%, D R=0.65$ ); (iii) modest (between 10 and $40 \%, D R=0.25$ ); and (iv) little (between $\mathrm{O}$ and $10 \%, \mathrm{DR}=0.05$ ), according to the classification of Klein et al (2007).

In addition to looking at individual crops and individual municipalities, we examined crop production and pollination services accounting for IBGE microregion limits in the state (Electronic Supplementary Material 1). This was done to provide information that can be used in multiple scales by municipality and state governments, stakeholders, and decisionmakers into the development of strategies and policies for economic development and pollination conservation. Furthermore, given the high value and importance of açai to local economies, we also calculated the crop production value and pollination service for each municipality without this crop; this was done to demonstrate the impact of this crop to the state's economy.

\section{Dependence of municipalities on crop pollination services}

For each municipality of Pará State, we determined the annual agricultural crop value and the pollination service value following the same procedure abovementioned. From IBGE, we acquired data on the total gross domestic product (GDP) of Pará and all municipalities in Pará state for the year of 2016 (Electronic Supplementary Material 2). We calculated the percentage of GDP related to the value of pollination service per each municipality in order to estimate a degree of dependence on crop pollination services. It is important to note that the açaí trade, which has high value in the state of Pará, is largely still based on informal markets, and much of its production is not included in the GDP calculation. This is particularly noticeable in the municipality of Igarapé Miri, where açaí production far exceeds total GDP value of the municipality. This will be discussed later (see the Discussion section).

\section{Results}

\section{Economic value of crop production in Pará}

We found 36 crops produced in Pará state (Table 1). Fifteen crops cultivated in Pará present no dependence for animal 
Table 1 Crops produced in Pará state, their dependence on pollinators and pollination service value.

\begin{tabular}{|c|c|c|c|c|}
\hline Crop & Dependence on pollinators & Dependence rate & Crop production value (2016) (US\$) & Pollination service value (US\$) \\
\hline Açaí & Great & 0.65 & $977,837,000$ & $635,594,050$ \\
\hline Cocoa (almond) & Essential & 0.95 & $197,486,500$ & $187,612,175$ \\
\hline Soybean (grain) & Modest & 0.25 & $393,745,250$ & $98,436,313$ \\
\hline Watermelon & Essential & 0.95 & $27,441,250$ & $26,069,188$ \\
\hline Orange & Modest & 0.25 & $36,856,500$ & $9,214,125$ \\
\hline Passion fruit & Essential & 0.95 & $9,339,000$ & $8,872,050$ \\
\hline Coco & Modest & 0.25 & $27,222,500$ & $6,805,625$ \\
\hline Oil palm (coconut bunch) & Little & 0.05 & $95,619,500$ & $4,780,975$ \\
\hline Tomato & Great & 0.65 & $4,535,250$ & $2,947,913$ \\
\hline Bean (grain) & Little & 0.05 & $20,863,250$ & $1,043,163$ \\
\hline Guava & Great & 0.65 & $1,425,500$ & 926,575 \\
\hline Papaya & Little & 0.05 & $6,508,750$ & 325,438 \\
\hline Cashew nut & Modest & 0.25 & 874,250 & 218,563 \\
\hline Avocado & Great & 0.65 & 245,750 & 159,738 \\
\hline Coffee (grain) Total & Modest & 0.25 & 310,250 & 77,563 \\
\hline Annatto (seed) & Little & 0.05 & $1,338,500$ & 66,925 \\
\hline Guarana (seed) & Great & 0.65 & 56,250 & 36,563 \\
\hline Tangerine & Little & 0.05 & 351,500 & 17,575 \\
\hline Melon & Essential & 0.95 & 15,250 & 14,488 \\
\hline Peanuts (shell) & Little & 0.05 & 49,500 & 2475 \\
\hline Manioc & No increase & 0 & $483,324,000$ & 0 \\
\hline Black pepper & No increase & 0 & $209,045,500$ & o \\
\hline Banana (bunch) & No increase & 0 & $167,798,500$ & 0 \\
\hline Corn (grain) & No increase & 0 & $117,626,250$ & 0 \\
\hline Pineapple & No increase & 0 & $92,205,750$ & o \\
\hline Rice (shell) & No increase & 0 & $37,331,000$ & o \\
\hline Sugar cane & No increase & 0 & $19,398,000$ & o \\
\hline Brazilian Lemon & Unknown & - & $17,837,500$ & - \\
\hline Palm heart & No increase & 0 & $1,203,250$ & 0 \\
\hline Sorghum (grain) & No increase & 0 & $1,054,000$ & o \\
\hline Rubber (coagulated lathe) & No increase & o & 855,250 & o \\
\hline Mallow (fiber) & No increase & 0 & 328,750 & 0 \\
\hline Onion & No increase & 0 & 157,500 & 0 \\
\hline Mango & No increase & 0 & 113,000 & 0 \\
\hline Sweet potato & No increase & o & 97,000 & 0 \\
\hline \multirow[t]{2}{*}{ Smoke (leaves) } & No increase & $\mathrm{o}$ & 22,750 & 0 \\
\hline & & Total & $2,950,519,500$ & $983,221,475$ \\
\hline
\end{tabular}

pollinators, and for one crop (i.e., Brazilian lemon, Citrus latifolia), there is no available data regarding its pollinator dependence for fruit production. Among the 15 crops produced in Pará state that we classified as not dependent, two crops were not previously classified by Giannini et al (2015a), sorgo, and palm heart, although they were previously included to IBGE's list. Sorgo is an herbaceous plant of Poaceae family, a predominantly autogamous and hermaphroditic species that does not require animal pollination for seed production (Stephens \& Quinby 1934, Muraya et al 2011). In
Pará, most of the palm heart production comes from açaí palms; although açaí palm fructification has a great dependence on animal pollination, we do not consider palm heart production to be directly related to animal pollination; thus, its production was also classified as not dependent.

In 2016, the total crop production value (CPV) for Pará state was of about US\$2.95 billion (Fig 1A). Five crops with the highest CPV accounted for more than $76 \%$ of the state's CPV (açaí, manioc, soybean, black pepper, and cocoa) (Table 1). From the 10 crops with the highest CPV, four crops 


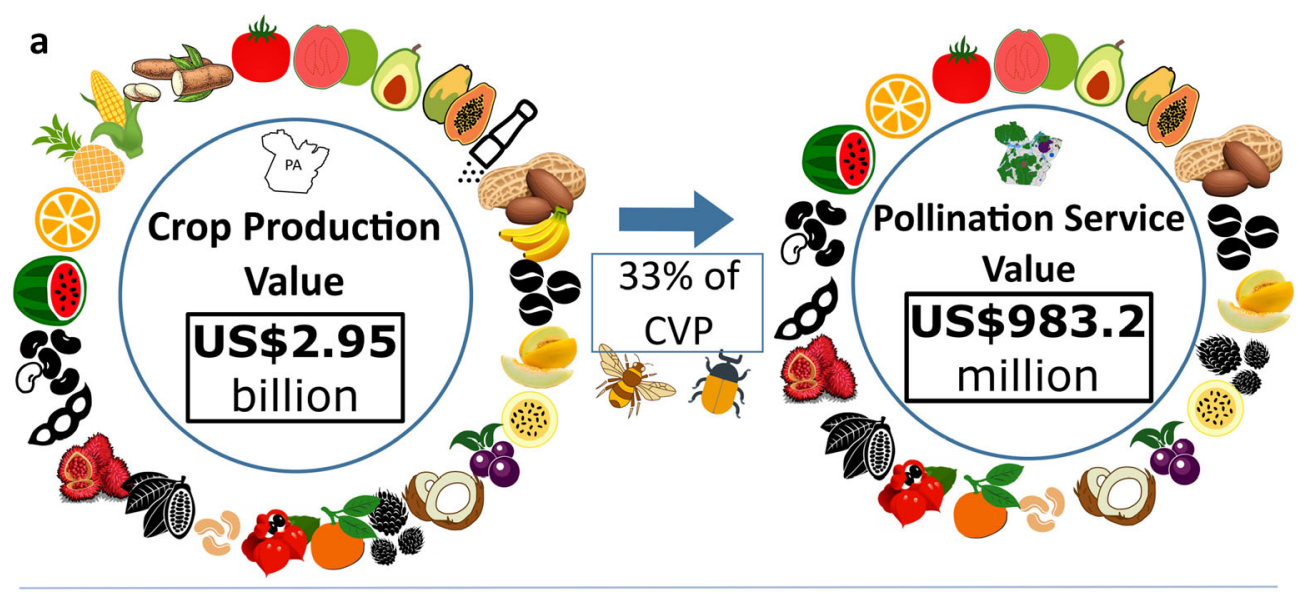

b

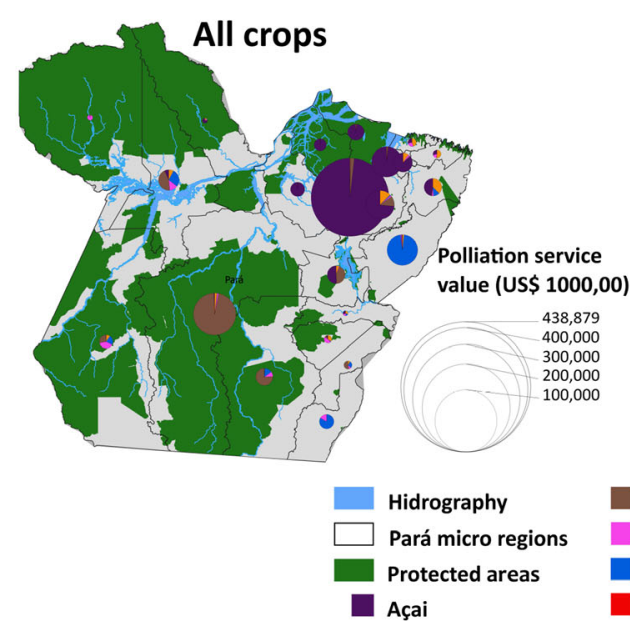

C

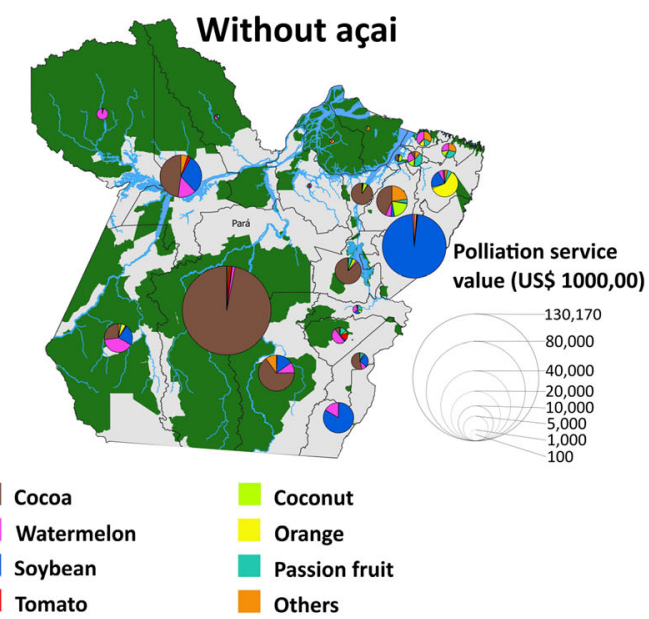

Fig 1 (a) The value of crop production and pollination services in Pará state; (b, c) crops with higher pollination service value for each micro region of Pará state, (b) all crops, and (c) without açai value. depend on animal pollination for fruit set, ranging in dependence from essential (cocoa) to little (oil palm) (Table 1). Açai production corresponds to one third of crop production in Pará (US\$ 977 million); therefore, crop production in the state without açai would be reduced to US\$1.9 billion (Electronic Supplementary Material 1).

\section{Economic value of pollination services}

We estimated the total pollination service value (PSV) to be US\$ 983.2 million (Fig $1 A$ ) in 2016 that is 33\% of CPV for Pará (Table 1). The crops with highest PSV were açaí palm (US\$635.6 million, $D R=0.65$ ), cocoa (US\$187.6 million, $\mathrm{DR}=0.95$ ), soybean (US\$98.4 million, $\mathrm{DR}=0.25$ ), and watermelon (US\$26.1 million, $D R=0.95)$ (Fig 1B, C), which accounted for $96 \%$ of pollination service value in the state (Table 1). Açai alone accounted for about $64 \%$ of PSV, therefore, without açai PSV would be US\$347.6 million (Electronic Supplementary Material 2).
Among the 22 microregions in Pará, the Cametá micro region alone presented $45 \%$ of the state's PSV. The micro regions with highest PSV were Cametá (US\$400 million), Altamira (US\$130 million), Paragominas (US\$68 million), Belém (US\$65 million), and Tomé-Açu (US\$59 million) (Table 2). Açai is the main crop produced in three of the highest PSV microregions (Cametá, Belém and Tomé-Açu), cocoa is the main dependent crop in Altamira micro region, and soybean is the main dependent crop in the Paragominas microregion. Watermelon production is spread throughout the state in all 22 microregions, having the higher values in Paragominas, Itaituba, and Santarem microregions respectively (Fig 1B).

Dependence of municipalities on crop pollination services for their local economy

Crops were produced in 143 municipalities; only one municipality (Santa Cruz do Arari) presented no crop production 
Table 2 The twenty-two microregions in Pará, their total crop production value, and pollination service value.

\begin{tabular}{lrr}
\hline State microregion & Crop production value (2016) (US\$) & Pollination service value (2016) (US\$) \\
\hline Cametá & $750,213,500$ & $438,878,787$ \\
Paragominas & $358,140,500$ & $68,100,837$ \\
Tomé-Açu & $263,353,750$ & $59,193,300$ \\
Altamira & $200,054,000$ & $130,965,162$ \\
Guamá & $182,894,000$ & $17,619,400$ \\
Santarém & $182,351,000$ & $30,947,475$ \\
Conceição do Araguaia & $158,425,000$ & $17,922,825$ \\
Tucuruí & $118,008,250$ & $22,995,137$ \\
Belém & $103,788,000$ & $65,385,875$ \\
Bragantina & $94,947,750$ & $4,810,475$ \\
Castanhal & $90,014,750$ & $27,098,812$ \\
Itaituba & $87,384,750$ & $13,304,412$ \\
São Felix do Xingu & $71,774,000$ & $21,426,175$ \\
Portel & $46,079,750$ & $14,659,025$ \\
Parauapebas & $44,496,250$ & $4,373,212$ \\
Óbidos & $43,582,500$ & $2,129,262$ \\
Arari & $41,718,500$ & $20,267,562$ \\
Redenção & $38,396,000$ & $4,755,012$ \\
Marabá & $28,876,500$ & $1,899,075$ \\
Salgado & $23,654,750$ & $5,148,512$ \\
Furos de Breves & $19,431,750$ & $10,951,112$ \\
Almeirim & $5,497,000$ & $1,959,237$ \\
\hline
\end{tabular}

(Fig 2A; Electronic Supplementary Material 2). The highest CPV can be found on eastern portion of Pará (Fig 2A), while the highest PSV can be found on northeastern areas (specially on Moju, Igarapé-Miri, and Abaetetuba), and in an isolated municipality on the central portion (Medicilândia) (Fig 2B).

The number of crops produced in the municipalities ranged from 1 to 23. CPVs ranged from about US\$35 thousand in Soure (lowest CPV) to about US\$460 million in Igarapé Miri (highest CPV). The 20 municipalities with the highest CPV accounted for $62 \%$ of crop production in the state, and one municipality alone (Igarapé Miri) accounted for $15.6 \%$ of CVP in Pará (Electronic Supplementary Material 2). As for PSV, Igarapé Miri and Abaetetuba presented the highest values, respectively, US\$ 298 and US\$106.8 million, whereas Soure and Palestina do Pará presented the lowest values (US\$8.7 and US\$1.3 thousand respectively).

Among the 144 municipalities, five do not rely on animal pollination for crop production and 64 have less than $1 \%$ of their GDP dependent on pollination services (Electronic Supplementary Material 2). For 62 municipalities, GDP dependence ranged from 1 to $10 \%$, and two municipalities (Medicilândia and Igarapé Miri) have more than $50 \%$ of their GDP based on pollination services. In thirteen municipalities (Table 3), one of three crops, açai (7 municipalities), cocoa (4 municipalities), and soy (2 municipalities), accounted for more than $50 \%$ of total CPV and four municipalities have more than $97 \%$ of their CPV associated with açai alone (Electronic Supplementary Material 2) (Fig 2C).

\section{Discussion}

Understanding the value of crop production and pollination services in both local and regional scales is vital for conservation planning in order to achieve the global biodiversity and sustainable development targets and food security to human populations in the long term (sustainably) (Wood et al 2018, Christmann 2019). In Pará state, twenty (out of 36) crops are dependent on animal pollinators. Pollination service value (PSV) is equivalent to approximately $33 \%$ of crop production value (CPV), and the total PSV is approximately equal to US\$983 million (year 2016) (Fig 1A). Two crops were highlighted with the highest CPV and PSV, açaí and cocoa. Thirteen municipalities (Table 3 ) have more than $10 \%$ of their GDP associated with pollination services and are, therefore, considered more dependent on crop pollination for their economic stability (Fig $2 \mathrm{C}$ ). Among them, Igarapé Miri and Abaetetuba (especially due to açaí) and Medicilandia (due to cocoa) are the three municipalities most dependent on pollination services. 

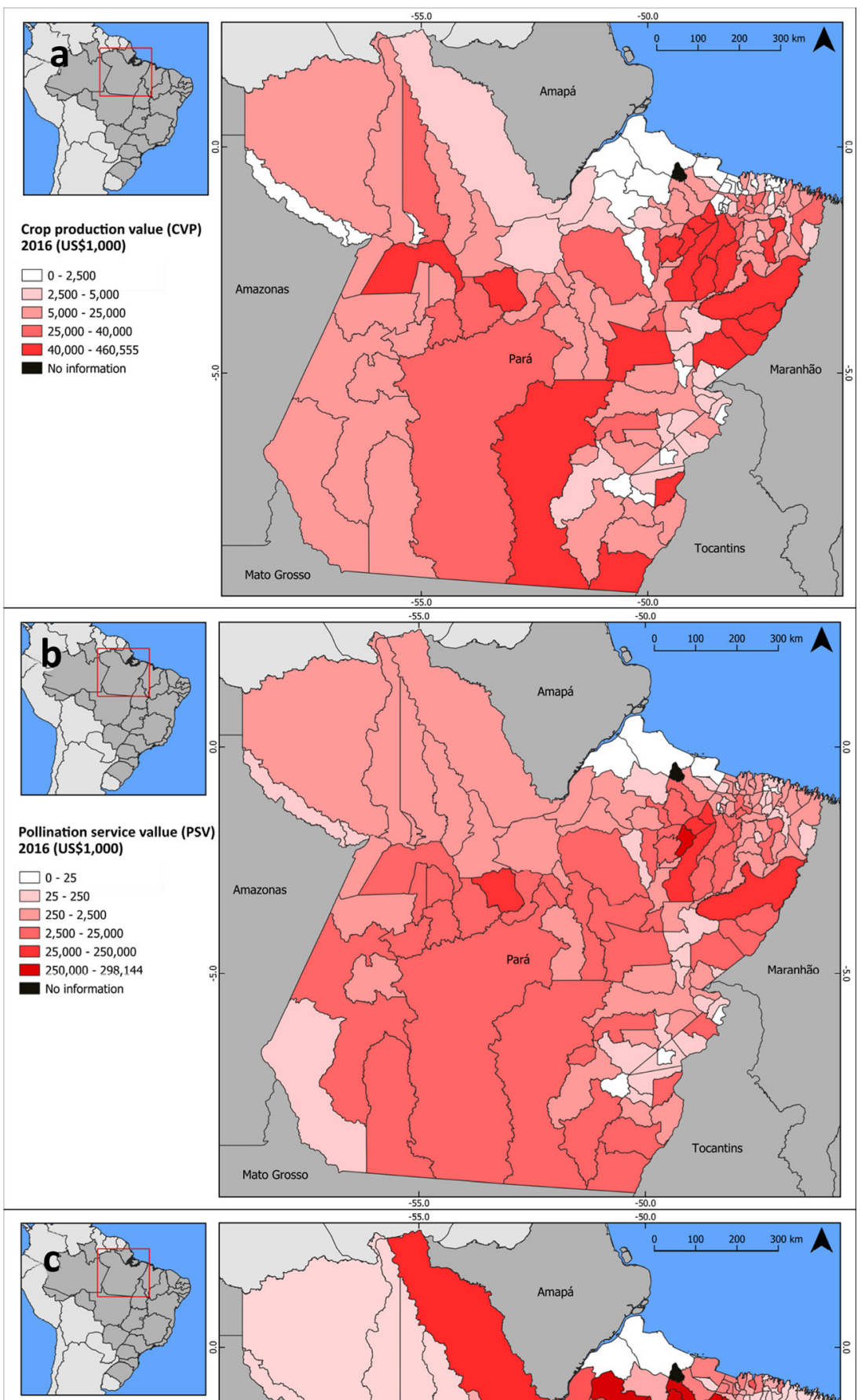

Percentage of GDP due to pollination service (2016)

$\square$ No dependence

$\square 0-10 \%$

$\square 10-20 \%$

$\square 20-30 \%$

$30-40 \%$
$40-50 \%$

$40-50 \%$
$50-83 \%$

No information

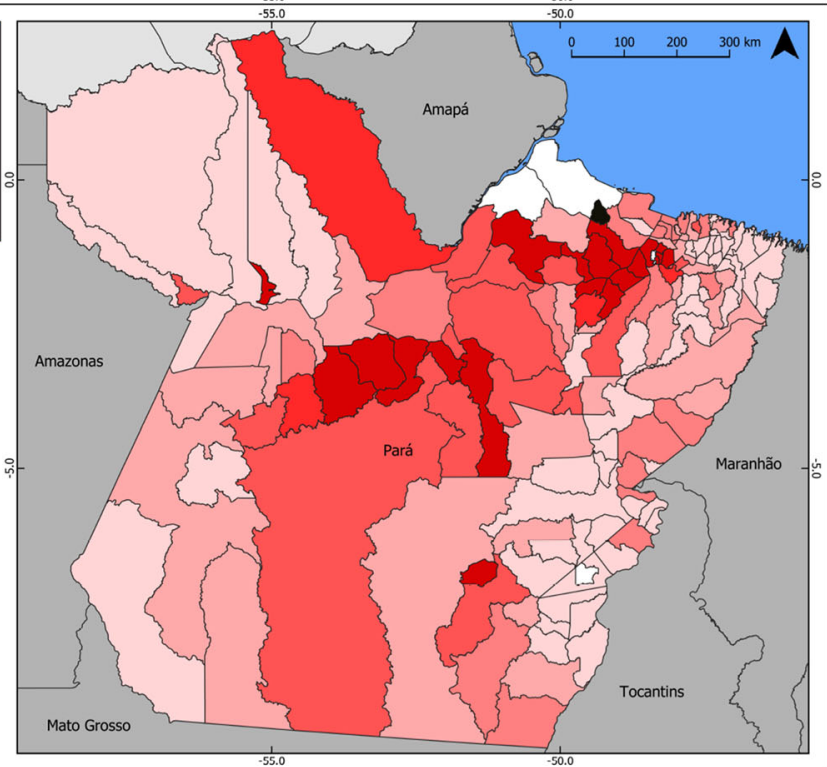


Fig 2 (a) Crop production value (CPV); (b) pollination service value (PSV) and (c) dependence on pollination service (percentage of GDP due to pollination service) of each municipality in Pará.

A similar percentage of PSV, when considering total CPV, was previously obtained for Brazil (30\%; Giannini et al 2015a), being soybean and coffee highlighted for Brazil as presenting the highest PSV (Giannini et al 2015a). For Pará, four crops presented the highest PSV associated with almost $96 \%$ of the total value. Açaí has recently been evaluated as highly dependent on pollinators and involving a complex system of interactions with bees, beetles, and ants; approximately 200 taxa were collected on açaí flowers (Campbell et al 2018). Cocoa, whose pollinator dependence is essential, also has a complex pollination system and a recent review discussed the uncertainty about its effective pollinators (Toledo-Hernandez et al 2017); thus, further studies are urgently needed. Soybean (the third crop with the highest PSV in Pará) is considered modestly dependent on pollination and is effectively pollinated by honeybees (Apis mellifera L.) (Milfont et al 2013, Blettler et al 2018), an exotic species in Brazil, that is highly generalist and widely distributed. Nevertheless, increased visitation by wild bees can also increase soybean production (Cunningham-Minnick et al 2019). However, little is still known about the role of pollination in soybean production in Brazil, since only one variety was studied (soybean cultivar BRS Carnauba; Milfont et al 2013), but for Pará this crop represents $10 \%$ of total PSV. The fourth crop with highest PSV is watermelon (essential dependence), with studies showing the importance of both stingless bees and honeybees as effective pollinators in Brazil (Bomfim et al 2014, Souza \& Malerbo-Souza 2005).
Overall, crop production in the state is strongly associated with land use (and deforestation) and water resources (Fig $1 \mathrm{~B})$. Soy production is strongly related to old deforestation frontiers (Gasparri et al 2013, Nepstad et al 2014) and its production in Pará is mainly concentrated on the eastern portion of the state, which coincides with most of the deforested areas in the Amazon deforestation arc. Cocoa production comes mainly from agroforestry system and is concentrated in the south and western portions of the state, where there is great concentration of protected areas. Açai production is concentrated around the state's capital, Belém, mainly in floodplains, but also in mainland, and constitutes the basis of economy, labor, and food security for traditional and lowincome populations in the region (Silva et al 2019).

Historically, açai consumption went from local communities to urban centers together with population exodus, achieving national and later international markets as a fashion and healthy food product that represents the support to traditional knowledge, and sustainable food production (Brondizio 2004). However, the industrialization phase of this crop (in the 1990's and 2000's) led to severe land use changes by supporting monoculture development in both floodplains and mainland (Weinstein \& Moegenburg 2004). Together with land use impacts, the socio-political history in the region produces different returns to local producers, which have low access to infrastructure and economic returns (Brondizio 2004, Silva et al 2019). Nevertheless, açai production represents the main source of income for local villages of several municipalities in Pará and one third of total crop production value in the state, presenting a great importance for the state's economy and food security.

Table 3 The thirteen most dependent municipalities considering the percentage of GDP related to pollination service.

\begin{tabular}{lccclcc}
\hline Municipality & $\begin{array}{l}\text { Number } \\
\text { of crops }\end{array}$ & GDP (US\$) & $\begin{array}{l}\text { Total crop production } \\
\text { value (2016) (US\$) }\end{array}$ & $\begin{array}{l}\text { Main crop } \\
\text { (\% of total CPV) }\end{array}$ & $\begin{array}{l}\text { Pollination service } \\
\text { value (2016) (US\$) }\end{array}$ & $\begin{array}{l}\text { GDP \% pollination } \\
\text { service }\end{array}$ \\
\hline Igarapé Miri (PA) & 14 & $91,838,500$ & $460,555,250$ & Açaí (99\%) & $298,143,775$ & 324.64 \\
Medicilândia (PA) & 18 & $141,450,000$ & $86,838,500$ & Cocoa (86\%) & $72,107,363$ & 50.98 \\
Abaetetuba (PA) & 18 & $312,313,750$ & $168,501,250$ & Açaí (97\%) & $106,839,000$ & 34.21 \\
Muaná (PA) & 7 & $58,894,000$ & $21,906,500$ & Açaí (99\%) & $14,170,338$ & 24.06 \\
Placas (PA) & 15 & $65,144,500$ & $27,122,000$ & Cocoa (51\%) & $13,542,738$ & 20.79 \\
São Sebastião da Boa Vista (PA) & 2 & $44,696,500$ & $13,019,000$ & Açaí (99\%) & $8,450,000$ & 18.91 \\
Uruará (PA) & 17 & $125,868,750$ & $30,064,500$ & Cocoa (65\%) & $20,167,738$ & 16.02 \\
Brasil Novo (PA) & 16 & $57,163,250$ & $11,527,500$ & Cocoa (75\%) & $8,294,363$ & 14.51 \\
Inhangapi (PA) & 13 & $27,833,000$ & $9,536,250$ & Açaí (54\%) & $3,761,625$ & 13.51 \\
Moju (PA) & 18 & $217,053,750$ & $74,713,000$ & Açaí (52\%) & $28,025,688$ & 12.91 \\
Bujaru (PA) & 11 & $122,488,500$ & $30,928,000$ & Açaí (73\%) & $14,905,550$ & 12.17 \\
Dom Eliseu (PA) & 17 & $164,022,000$ & $92,037,500$ & Soybean (78\%) & $18,733,275$ & 11.42 \\
Mojuí dos Campos (PA) & 20 & $34,328,250$ & $17,408,250$ & Soybean (53\%) & $3,487,988$ & 10.16 \\
\hline
\end{tabular}

${ }^{1}$ This result is due to the informal trade of açaí, which is not included in GDP 
Thirteen municipalities had more than $10 \%$ of their GDP associated with PSV (Electronic Supplementary Material 2). Among them stands out Igarapé Miri with high açaí production and informal market, whose values are clearly not incorporated into GDP or local databases. These thirteen municipalities are the more dependent on pollinators and public policies towards the conservation of pollinating insects, as well as ecological intensification farming practices are particularly important for their economic development and population well-being (Kleijn et al 2019) (Table 3). Here we have shown how agriculture plays a main role in the local economy of Eastern Amazon municipalities, but still there is a pressing need to better understand the local economy structure, the role of pollination services, and the threats posed by climate and land use changes to human livelihoods. The non-inclusion of açai production to local GDPs provides a glimpse to the lack of local data and knowledge from this region.

Highly dependent municipalities in Pará had more than 50\% of CPV associated only to three crops, and four municipalities have more than $97 \%$ of their CPV associated with açaí alone (Abaetetuba, Igarapé Miri, Muana, São Sebastião da Boa Vista). The diversity of agricultural crops was previously related to the concept of resilience (Gbetibouo et al 2010), because high diversity implies a greater chance of assimilating possible impacts or reductions in the production of one or a few crops. Also, crop diversity would support more agricultural jobs, grounding local livelihoods and socio-economic development (Garibaldi \& Pérez-Mendez 2019). Thus, it can be suggested that municipalities whose production depends solely on a single crop discuss their current socio-economic plans, aiming to enhance crop diversification.

Public policies for pollinator conservation have already been suggested, being particularly important for the conservation of natural areas near or within crops (Garibaldi et al 2014). This is particularly important for açaí, a crop mainly pollinated by small stingless bees (such as small Trigona-like bees, Campbell et al 2018), with short flight ranges and more commonly found on well-preserved habitats, due to their nesting requirements (Borges et al 2020); in fact, crops near forested areas presented higher fruit production (Campbell et al 2018). In this sense, conservation of legal reserves and maintenance of forest patches within rural areas is a particularly important mechanism in Brazil for the conservation and sustainable use of biodiversity (Garibaldi et al 2011, Metzger et al 2019), which should be encouraged and regulated, especially in the Amazon biome states (Freitas et al 2015, Christmann 2019, Metzger et al 2019, Nunes et al 2019).

Protected areas are also important to safeguard pollinator diversity and deliver crop pollination services (Hipólito et al 2019). In fact, agricultural production is key to ensure sustainable development (DeClerck et al 2016, Garibaldi \& Pérez-Mendez 2019) and is associated with all the 17 Sustainable Development Goals (SDGs), integrating the three dimensions of sustainable development-economic growth, social inclusion, and environmental protection (FAO 2018). In addition, tropical forest conservation has been increasingly associated with socio-economic development through the provision of various ecosystem services (Constanza et al 1997, 2014), and a better understanding of non-listed local crops as well as their effective pollinators is required for the development of local strategies. The value of standing forest exceeds other land uses, and deforestation can result in high social (Franklin \& Pindyck 2018) and economic costs (Hipólito et al 2019). Integrating long used local crops to socioeconomic systems seems to be a fundamental tool for developing sustainable development in forest ecosystems. In a rapidly changing world, anticipating the impact of climate change is also indispensable and scenarios for pollinators in the state of Pará have been forecasted, suggesting that crop pollinator bees will potentially be highly affected by climate changes by 2050 (Giannini et al 2020).

Future work should address the knowledge gap about the identification of crop pollinators for Amazonian agricultural crops, as still little is known about the species that provide this service. Additionally, many crops of regional interest consumed by local fisherman communities (Ribeirinhos) have not yet been studied; the pollination system of their farming activities is little known and its importance for family farming in Amazonian traditional communities has not been assessed.

Acknowledgments We are grateful to Coordenação de Aperfeiçoamento de Pessoal de Nível Superior-Brasil (CAPES)-Finance Code 001 and to National Council for Scientific and Technological Development (CNPq) (process numbers 381187/2019-5; 312250/2018-5) for financial support and to Tom Breeze and one anonymous reviewer for suggestions and contributions to a first version of this manuscript.

Authors' Contribution RCB, RMB, and TCG-conceptualization, data curation, formal analysis. TCG, VLIF-funding acquisition. RCB, RMB, and TCG -investigation, methodology. RCB, TCG-project administration. TCG, VLIF-resources. TCG-supervision. RCB, TCG - validation, visualization, writing (original draft). RCB, RMB, VLIF, and TCG-writing (review and editing).

Electronic supplementary material The online version of this article (https://doi.org/10.1007/s13744-020-00791-w) contains supplementary material, which is available to authorized users.

Open Access This article is licensed under a Creative Commons Attribution 4.0 International License, which permits use, sharing, adaptation, distribution and reproduction in any medium or format, as long as you give appropriate credit to the original author(s) and the source, provide a link to the Creative Commons licence, and indicate if changes were made. The images or other third party material in this article are included in the article's Creative Commons licence, unless indicated otherwise in a credit line to the material. If material is not included in the article's Creative Commons licence and your intended use is not permitted by statutory regulation or exceeds the permitted use, you will need to obtain permission directly from the copyright holder. To view a copy of this licence, visit http://creativecommons. org/licenses/by/4.0/. 


\section{References}

Almeida CA, Coutinho AC, Esquerdo JC, Dalla M, Adami M, Venturieri A, Diniz CG, Dessay N, Durieux L, Gomes AR (2016) High spatial resolution land use and land cover mapping of the Brazilian legal Amazon in 2008 using Landsat-5/TM and MODIS data. Acta Amaz 46:291-302. https://doi.org/10.1590/1809-4392201505504

Assunção J, Rocha R (2019) Getting greener by going black: the effect of blacklisting municipalities on Amazon deforestation. Environ Dev Econ 24:115-137. https://doi.org/10.1017/S1355770X18000499

Barfield AS, Bergstrom JC, Ferreira S, Covich AP, Delaplane KS (2015) An economic valuation of biotic pollination services in Georgia. J Econ Entomol 108:388-398. https://doi.org/10.1093/jee/touo45

Blettler DC, Fagúndez GA, Caviglia OP (2018) Contribution of honeybees to soybean yield. Apidologie 49:101-111. https://doi.org/10.1007/ s13592-017-0532-4

Bomfim IGA, Bezerra ADM, Nunes AC, Aragão FAS, Freitas BM (2014) Adaptive and foraging behavior of two stingless bee species (Apidae: Meliponini) in greenhouse mini watermelon pollination. Sociobiology 61:502-509. https://doi.org/10.13102/sociobiology.v61i4.502-509

Bommarco R, Kleijn D, Potts SG (2013) Ecological intensification: harnessing ecosystem services for food security. Trends Ecol Evol 28: 230-238. https://doi.org/10.1016/j.tree.2012.10.012

Bommarco R, Vico G, Hallin S (2018) Exploiting ecosystem services in agriculture for increased food security. Glob Food Sec 17:57-63. https://doi.org/10.1016/j.gfs.2018.04.001

Borges RC, Padovani K, Imperatriz-Fonseca VL, Giannini TC (2020) A dataset of multi-functional ecological traits of Brazilian bees. Sci Data 7:120. https://doi.org/10.1038/s41597-020-0461-3

Braat LC, de Groot R (2012) The ecosystem services agenda: bridging the worlds of natural science and economics, conservation and development, and public and private policy. Ecosyst Serv 1:4-15. https://doi. org/10.1016/j.ecoser.2012.07.011

BRAZIL, INPE. 2019. INPE consolida $7.536 \mathrm{~km} 2$ de desmatamento na Amazônia em 2018. Available at http://www.obt.inpe.br/OBT/ noticias/inpe-consolida-7-536-km2-de-desmatamento-na-amazoniaem-2018. Access 12 October 2019

Breeze TD, Gallai N, Garibaldi LA, Li XS (2016) Economic measures of pollination services: shortcomings and future directions. Trends Ecol Evol 31:927-939. https://doi.org/10.1016/j.tree.2016.09.002

Brondizio ES (2004) From staple to fashion food: shifting cycles and shifting opportunities in the development of the açaí palm fruit economy in the amazon estuary. In: Zarin D, Alavalapati JRR, Putz FE, Schmink $M$ (eds) Working forests in the Neotropics: conservation through sustainable management? Columbia University Press, New York, pp 339-365

Brondizio ES, Safar CAM, Siqueira AD (2002) The urban market of Açai fruit (Euterpe oleracea Mart.) and rural land use change: ethnographic insights into the role of price and land tenure constraining agricultural choices in the Amazon estuary. Urban Ecosyst 6:67-97

Camilotti VL, Pinho P, Brondízio ES, Escada MIS (2020) The importance of Forest extractive resources for income generation and subsistence among Caboclos and colonists in the Brazilian Amazon. Hum Ecol 48: 17-31. https://doi.org/10.1007/s10745-020-00127-7

Campbell AJ, Carvalheiro LG, Maués MM, Jaffé R, Giannini TC, Freitas MAB, Coelho BWT, Menezes C (2018) Anthropogenic disturbance of tropical forests threatens pollination services to açaí palm in the Amazon river delta. J Appl Ecol 55:1725-1736. https://doi.org/10. $1111 / 1365-2664.13086$

Christmann S (2019) Do we realize the full impact of pollinator loss on other ecosystem services and the challenges for any restoration in terrestrial areas? Restor Ecol 27:720-725. https://doi.org/10.1111/rec. 12950

Constanza R, Groot R, Sutton P, van der Ploeg S, Anderson SJ, Kubiszewski I, Farber S, Turner RK (2014) Changes in the global value of ecosystem services. Glob Environ Chang 26:152-158. https://doi. org/10.1016/j.gloenvcha.2014.04.002

Costa WF, Ribeiro M, Saraiva AM, Imperatriz-Fonseca VL, Giannini TC (2018) Bat diversity in Carajás National Forest (Eastern Amazon) and potential impacts on ecosystem services under climate change. Biol Conserv 218:200-210. https://doi.org/10.1016/j.biocon.2017.12.034

Constanza R, D'Arge R, Groot R, Farber S, Grasso M, Hannon B, Limburg K, Naeem S, O'Neill RV, Paruelo J, Raskin RG, Sutton P, van der Belt M (1997) The value of the world's ecosystem services and natural capital. Nature 387:253-260. https://doi.org/10.1038/387253ao

Cunningham-Minnick MJ, Peters VE, Crist TO (2019) Nesting habitat enhancement for wild bees within soybean fields increases crop production. Apidologie 50:833-844. https://doi.org/10.1007/s13592019-00691-y

Daily GC, Alexander S, Ehrlich PR, Goulder L, Lubchenco J, Matson PA, Mooney HA, Postel S, Schneider SH, Tilman D, Woodwell GM (1997) Ecosystem services: benefits supplied to human societies by natural ecosystems. Issues Ecol 2:1-16

DeClerck FAJ, Jones SK, Attwood S, Bossio D, Givetz E, Chaplin-Kramer B, Enfors E, Fremier AK, Gordon L, Kizito F, Noriega IL, Matthews N, McCartney M, Meacham M, Noble A, Quintero M, Remas R, Soppe R, Willemen L, Wood SLR, Zhang W (2016) Agricultural ecosystems and their services: the vanguard of sustainability? Curr Opin Environ Sustain 23:92-99. https://doi.org/10.1016/j.cosust.2016.11.016

Díaz S, Demissew S, Carabias J, Joly C, Lonsdale M, Ash N, Larigauderie A, Adhikari JR, Arico S, Báldi A, Bartuska A, Baste IA, Bilgin A, Brondizio E, Chan KM, Figueroa VE, Duraiappah A, Fischer M, Hill R, Koetz $T$, Leadley $\mathrm{P}$, Lyver P, Mace GM, Martin-Lopez B, Okumura M, Pacheco D, Pascual U, Pérez ES, Reyers B, Roth E, Saito O, Scholes RJ, Sharma N, Tallis H, Thaman R, Watson R, Yahara T, Hamid ZA, Akosim C, Al-Hafedh $\mathrm{Y}$, Allahverdiyev R, Amankwah E, Asah ST, Asfaw Z, Bartus G, Brooks LA, Caillaux J, Dalle G, Darnaedi D, Driver A, Erpul G, Escobar-Eyzaguirre P, Failler P, Fouda ALMM, Fu B, Gundimeda $\mathrm{H}$, Hashimoto $S$, Homer F, Lavorel S, Lichtenstein $G$, Mala WA, Mandivenyi W, Matczak P, Mbizvo C, Mehrdadi M, Metzger JP, Mikissa JB, Moller H, Mooney HA, Mumby P, Nagendra $\mathrm{H}$, Nesshover C, Oteng-Yeboah AA, Pataki G, Roué M, Rubis J, Schultz $M$, Smith $P$, Sumaila R, Takeuchi K, Thomas S, Verma M, Yeo-Chang $Y$, Zlatanova D (2015) The IPBES conceptual framework - connecting nature and people. Curr Opin Environ Sustain 14:1-16. https://doi. org/10.1016/j.cosust.2014.11.002

Díaz S, Settele J, Brondízio ES, Ngo HT, Agard J, Arneth A, Balvanera P, Brauman KA, Butchart SHM, Chan KMA, Garibaldi LA, Ichii K, Liu J, Subramanian SM, Midgley GF, Miloslavich P, Molnár Z, Obura D, Pfaff A, Polasky S, Purvis A, Razzaque J, Reyers B, Chowdhury RR, Shin Y, Visseren-Hamakers I, Willis KJ, Zayas CN (2019) Pervasive humandriven decline of life on Earth points to the need for transformative change. Science 366:1-10. https://doi.org/10.1126/science.aax3100

FAO (2018) Transforming food and agriculture to achieve the SDGs. Food and Agriculture Organization of the United Nations, Rome, 76

FAO, IFAD, UNICEF, WFP, WHO. 2019. The State of Food Security and Nutrition in the World 2019: safeguarding against economic slowdowns and downturns. Food and Agriculture Organization of the United Nations, Rome, 215

Franklin SL, Pindyck RS (2018) Tropical forests, tipping points, and the social cost of deforestation. Ecol Econ 153:161-171. https://doi.org/10. 1016/j.ecolecon.2018.06.003

Freitas MAB, Vieira ICG, Albernaz ALKM, Magalhães JLL, Lees AC (2015) Floristic impoverishment of Amazonian floodplain forests managed for açaí fruit production. For Ecol Manag 351:20-27. https://doi.org/ 10.1016/j.foreco.2015.05.008

Gallai N, Vaissiere BE (2009) Guidelines for the economic valuation of pollination services at a national scale. Food and Agriculture Organization of the United Nations, Rome, p 20

Gallai N, Salles JM, Settele J, Vaissière BE (2009) Economic valuation of the vulnerability of world agriculture confronted with pollinator 
decline. Ecol Econ 68:810-821. https://doi.org/10.1016/j.ecolecon. 2008.06.014

Garibaldi LA, Pérez-Mendez N (2019) Positive outcomes between crop diversity and agricultural employment worldwide. Ecol Econ 164: 106358. https://doi.org/10.1016/j.ecolecon.2019.106358

Garibaldi LA, Steffan-Dewenter I, Kremen C, Morales JM, Bommarco R, Cunningham SA, Carvalheiro LG, Chacoff NP, Duenhöffer JH, Greenleaf SS, Holzschuh A, Isaacs R, Krewenka K, Mandelik Y, Mayfield MM, Morandin LA, Potts SG, Ricketts TH, Szentgyörgyi H, Viana BF, Westphal C, Winfree R, Klein AM (2011) Stability of pollination services decreases with isolation from natural areas despite honey bee visits. Ecol Lett 14:1062-1072. https://doi.org/10.1111/j.14610248.2011.01669.x

Garibaldi LA, Carvalheiro LG, Leonhardt SD, Aizen MA, Blaauw BR, Isaacs R, Kuhlmann M, Kleijn D, Klein AM, Kremen C, Morandin L, Scheper J, Winfree $R$ (2014) From research to action: enhancing crop yield through wild pollinators. Front Ecol Environ 12:439-447. https://doi. org/10.1890/130330

Gasparri NI, Grau HR, Angonese JG (2013) Linkages between soybean and neotropical deforestation: coupling and transient decoupling dynamics in a multi-decadal analysis. Glob Environ Chang 23:1605-1614. https://doi.org/10.1016/j.gloenvcha.2013.09.007

Gbetibouo GA, Ringles C, Hassan R (2010) Vulnerability of the South African farming sec-tor to climate change and variability: an indicator approach. Nat Res Forum 34:175-187. https://doi.org/10.1111/j.14778947.2010.01302.x

Giannini TC, Cordeiro GD, Freitas BM, Saraiva AM, Imperatriz-Fonseca VL (2015a) The dependence of crops for pollinators and the economic value of pollination in Brazil. J Econ Entomol 108:849-857. https:// doi.org/10.1093/jee/tovo93

Giannini TC, Boff S, Cordeiro GD, Cartolano EA Jr, Vaiga AK, ImeratrizFonseca VL, Saraiva AM (2015b) Crop pollinators in Brazil: a review of reported interactions. Apidologie 46:209-223. https://doi.org/10. 1007/s13592-014-0316-z

Giannini TC, Costa WF, Borges RC, Miranda L, Costa CPW, Saraiva AM, Imperatriz-Fonseca VL (2020) Climate change in the Eastern Amazon: crop-pollinator and occurrence-restricted bees are potentially more affected. Reg Environ Chang 20:9. https://doi.org/10.1007/s10113020-01611-y

Hipólito J, Sousa BSB, Borges RC, Brito RM, Jaffé R, Dias S, ImperatrizFonseca VL, Giannini TC (2019) Valuing nature's contribution to people: the pollination services provided by two protected areas in Brazil. Glob Ecol Conserv 20:e00782. https://doi.org/10.1016/j.gecco.2019. e00782

IBGE (1990) Divisão do Brasil em mesoregiões e microregiões geográficas. Fundação do Instituto Brasileiro de Geografia e Estatística, Rio de Janeiro, p 135

IBGE (2017) Pesquisa Nacional por Amostra de Domicílios: IDHM. https://cidades.ibge.gov.br/brasil/pa/pesquisa/37/30255. Accessed 25 Mai 2019

IBGE (2018) Pesquisa Nacional por Amostra de Domicílios: panorama. https://cidades.ibge.gov.br/brasil/pa/panorama. Accessed 25 Mai 2019

Iorio M, Monni S (2020) National growth and regional (under)development in Brazil: the case of Pará in the Brazilian Amazon. In: Tvaronavičienè M, Ślusarczyk B (eds) Energy transformation towards sustainability. Elsevier Science, Amsterdam, pp 71-84

Kleijn D, Bommarco R, Fijen TPM, Garibaldi LA, Potts SG, van der Putten WHL (2019) Ecological intensification: bridging the gap between science and practice. Trends Ecol Evol 34:154-166. https://doi.org/10. 1016/j.tree.2018.11.002

Klein AM, Vaissiere BE, Cane JH, Steffan-Dwenter I, Cunningham SA, Kremen C, Tscharntke T (2007) Importance of pollinators in changing landscapes for world crops. Proc R Soc B Biol Sci 274:303-313. https:// doi.org/10.1098/rspb.2006.3721
Metzger JP, Bustamante MMC, Ferreira J, Fernandes GW, Libran-Embid F, Pillar VD, Prist PR, Rodrigues RR, Vieira ICG, Overbeck GE (2019) Why Brazil needs its legal reserves. Perspect Ecol Conserv 17:91-103. https://doi.org/10.1016/j.pecon.2019.07.002

Milfont MO, Rocha EEM, Lima AON, Freitas BM (2013) Higher soybean production using honeybee and wild pollinators, a sustainable alternative to pesticides and autopollina-tion. Environ Chem Lett 11:335341. https://doi.org/10.1007/s10311-013-0412-8

Miranda LS, Imperatriz-Fonseca VL, Giannini TC (2019) Climate change impact on ecosystem functions provided by birds in southeastern Amazonia. PLoS One 14(4):e0215229. https://doi.org/10.1371/ journal.pone.0215229

Muraya MM, Mutegi E, Geiger HH, Villiers SM, Sagnard F, Kanyenji BM, Kiambi D, Parzies HK (2011) Wild sorghum from different ecogeographic regions of Kenya display a mixed mating system. Theor Appl Genet 122:1631-1639. https://doi.org/10.1007/s00122-011-15605

Nepstad D, McGrath D, Stickler C, Alencar A, Azevedo A, Swette B, Bezerra T, DiGiano M, Shimada J, Motta RS, Armijo E, Castello L, Brando P, Hansen MC, McGrath-Horn M, Carvalho O, Hess L (2014) Slowing Amazon deforestation through public policy and interventions in beef and soy supply chains. Science 344:1118-1123. https:// doi.org/10.1126/science.1248525

Novais SMA, Nunes CA, Santos NB, Dámico AR, Fernandes GW, Quesada $\mathrm{M}$, Braga RF, Neves ACO (2016) Effects of a possible pollinator crisis on food crop production in Brazil. PLoS One 11(11):e0167292. https:// doi.org/10.1371/journal.pone.0167292

Nunes S, Barlow J, Gardner T, Sales M, Monteiro D, Souza C (2019) Uncertainties in assessing the extent and legal compliance status of riparian forests in the eastern Brazilian Amazon. Land Use Policy 82: 37-47. https://doi.org/10.1016/j.landusepol.2018.11.051

O'Neill BC, Done JM, Gettelman A, Lawrence P, Lehner F, Lamarque JF, Lin L, Monaghan AJ, Oleson K, Ren X, Sanderso BM, Tebaldi C, Weitzel $M, X u Y$, Anderson B, Fix MJ, Levis S (2018) The benefits of reduced anthropogenic climate changE (BRACE): a synthesis. Clim Chang 146: 287-301. https://doi.org/10.1007/s10584-017-2009-x

PAM (2016) Produção Agrícola Municipal. https://sidraibgegovbr/ pesquisa/pam/tabelas Accessed 15 Mai 2019

Pires JM, Prance GT (1985) The vegetation types of the Brazilian Amazon. In: Prance GT, Lovejoy TE (eds) Key environments: Amazonia. Pergamon Press, Oxford, pp 109-115

Potts SG, Imperatriz-Fonseca V, Ngo HT, Aizen MA, Biesmeijer JC, Breeze TD, Dicks LV, Garibaldi LA, Hill R, Settele J, Vanbergen AJ (2016) Safeguarding pollinators and their values to human well-being. Nature 540:220-229. https://doi.org/10.1038/nature20588

Prevedello JA, Winck GR, Weber MM, Nichols E, Sinervo B (2019) Impacts of forestation and deforestation on local temperature across the globe. PLoS One 14(3):e0213368. https://doi.org/10.1371/journal. pone. 0213368

Schmidhuber J, Tubiello FN (2017) Global food security under climate change. PNAS 104(50):19703-19708. https://doi.org/10.1073/pnas. 0701976104

Silva JIS, Rebello FK, Lima HV, Santos MAS, Santos PC, Lopes MLB (2019) Socio-economics of acai production in rural communities in the Brazilian Amazon: a case study in the municipality of Igarapé-Miri, State of Pará. J Agric Sci 11(5):215-224

Silva AO, Mera WYWL, Santos DCR, Souza DP, Silva CGN, Raiol LL, Silva AMG, Silva DAS, Viegas EJM (2020) Açaí (Euterpe oleracea Mart) production study: economic and productive aspects based on 20152017. Brazilian J Dev 6(1):1629-1641

Sonter L, Herrera D, Barrett DJ, Galfors GL, Moran CL, Soares-Filho BS (2017) Mining drives extensive deforestation in the Brazilian Amazon. Nat Commun 8:1-7. https://doi.org/10.1038/s41467-017-00557-w

Souza FF, Malerbo-Souza DT (2005) Entomofauna visitante e produção de frutos em melancia (Citrullus lanatus) - Cucurbitaceae. Acta Sci Agron 27:449-454. https://doi.org/10.4025/actasciagron.v27i3.1408 
Souza-Filho PWM, de Souza EB, Silva RO, Nascimento WR, Mendonça BV, Guimarães JTF, Dell'Agnol R, Siqueira JO (2016) Four decades of land-cover, land-use and hydroclimatology changes in the Itacaiúnas River watershed, southeastern Amazon. J Environ Manag 167:175184. https://doi.org/10.1016/j.jenvman.2015.11.039

Stephens JC, Quinby JR (1934) Anthesis, pollination, and fertilization in Sorghum. J Agric Res 49:123-136

Toledo-Hernández M, Wanger TC, Tscharntke T (2017) Neglected pollinators: can enhanced pollination services improve cocoa yields? A review. Agric Ecosyst Environ 247:137-148. https://doi.org/10.1016/j. agee.2017.05.021

United Nations (2015) United Nations Millenium Development Goals Report. Office 75. Ac-cessed 13 Sep 2019, Available from: http:// www.un.org/millenniumgoals/2015_MDG_Report/pdf/MDG\% 202015\%20rev\%20\%28July\%201\%29.pdf
Weinstein S, Moegenburg S (2004) Açaí palm management in the Amazon Estuary: course for conservation or passage to plantations? Conserv Soc 2(2):315-346

Wood SLR, Jones SK, Johnson JA, Brauman KA, Chaplin-Kramer R, Fremier A, Girvetz E, Gordon $D$, Kappel CV, Mandle L, Mulligan M, O'Farrel P, Smith WK, Willemen L, Zhang W, DeClerck F (2018) Distilling the role of ecosystem services in the sustainable development goals. Ecosyst Serv 29:70-82. https://doi.org/10.1016/j.ecoser. 2017.10.010

Publisher's Note Springer Nature remains neutral with regard to jurisdictional claims in published maps and institutional affiliations. 